\title{
METHOD FOR KEEPING RBOF WASTE WITHIN EPA pH LIMITS FOR NONHAZARDOUS WASTE (U)
}

by C. L. Cobb, et al.

Westinghouse Savannah River Company

Savannah River Site

Aiken, South Carolina 29808
WSRC-RP $-92-340$

DE93 008506

E. W. Baumann

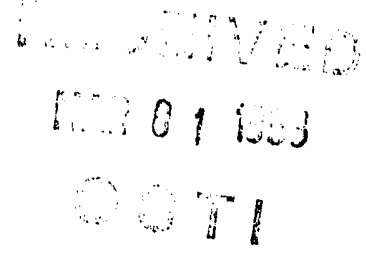

This paper was prepared in connection with work done under Contract No. DE-AC09-89SR18035 with the U. S. Department of Energy. By acceptance of this paper, the publisher and/or recipient acknowledges the U. S. Government's right to retain a nonexclusive, royalty-free license in and to any copyright covering this paper, along with the right to reproduce and to authorize others to reproduce all or part of the copyrighted paper.

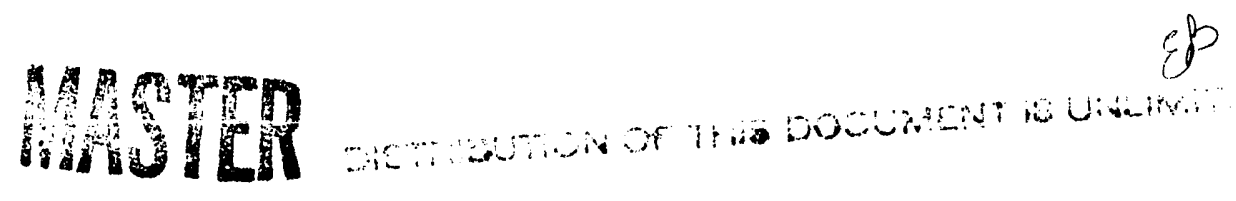




\section{DISCLAIMER}

This report was prepared as an account of work sponsored by an agency of the United States Government. Neither the United States Government nor any agency thereof, nor any of their employees, makes any warranty, express or implied, or assumes any legal liability or resfunsibility for the accuracy, completeness, or usefulness of any information, apparatus, product, or process disclosed, or represents that its use would not infringe privately owned rights. Reference herein to any specific commercial product, process, or service by trade name, trademark, manufacturer, or otherwise does not necessarily constitute or imply its endorsement, recommendation, or favoring by the United States Government or any agency thereof. The views and opinions of authors expressed herein do not necessarily state or reflect those of the United States Govemment or any agency thereof.

This report has been reproduced directly from the best available copy.

Available to DOE and DOE contractors from the Office of Scientific and Technical Information, P.O. Box 62, Oak Ridge, TN 37831; prices available from (615) 576-8401, FTS 626-8401.

Available to the public frow the National Technical Information Service, U.S. Department of Commerce, 5285 Port Royal Rd, Springfield, VA 22161. 
February 18, 1992

To:

A. L. Blancett, 773-A

From:

C. L. Cobb, 773-A

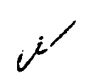

W. N. Wilson, 773-A

E. W. Baumann, 773-41A

J. E. Young, 773-A

Distribution:

F. R. Graham, 773-A

S. W. Stump, 244-2H

T. R. Cowlam, 244-2H

D.R. Johnson, 707-H

D. K. Parkman, 221-H

P. F. Cloessner, 773-A

M. F. Herlihy, 221-H

S. W. ORear, Jr., 244-2H

Derivative Classifier

S. A. Yano, 221-H

\section{Method for Keeping RBOF Waste within EPA pH Limits for Nonhazardous Waste (U) \\ Conclusion}

A system to control corrosion, while reducing the amount of hazardous waste generated, is proposed for the RBOF receiving basin. Details of the chemistry, experimental seup, and methods for monitoring $\mathrm{pH}$ are included.

\section{Summary}

Solutions with a pH of > 12.5 are considered RCRA hazardous waste (characteristic corrosive). The Receiving Basin for Offsite Fuel (RBOF) currently adjusts its waste to a pH > 12.5 to inhibit corrosion of the waste tanks. As of May 8, 1992 this waste will be banned from land disposal (third-third) and will exceed Waste Management acceptance criteria. RBOF proposed, as a solution to this problem, ${ }^{1}$ to buffer the waste with a carbonate/bicarbonace buffer 10 a $\mathrm{pH}>10$, then use nitrite as the corrosion inhibitor. $\mathrm{A}$ pH of $\geq 10$ is necessary for corrosion inhibition at a NO2- concentration of $0.86 \mathrm{M}^{2}{ }^{2}$ RBOF proposed to monitor the pH with a pH meter, backed up by Alizarin Yellow indicator. A worst-case scenario in which the caustic feed blocked and only acid was released into the tank was used to determine the amount of buffer salts needed.

We tested this approech and found that the amounts of carbonate/bicarbonate salts required would be insoluble. We have demonstrated tha $\mathrm{CO}_{2}$ ges could be bubbled through the solution to lower the pH without adding additional salts. ${ }^{3}$ We also suggested an altemative indicator, Azoviolet 4,5 and an inexpensive, commercialiy available instrument for reading the indicator. 6 The colormetric pH reading would serve as a supplement and confirmation of a pH meter reading. From the literature we found that the $\mathrm{NaNO}_{2}$ solution would have to be used within 24 hours the to the instability of neutral $\mathrm{NaNO}_{2}$ solutions ${ }^{7}$ and that the concentration of the $\mathrm{NaNO}_{2}$ solution would have to be greater than the standard $30 \%$ plant solution. 


\section{Experimento! netalle}

Two indicators, Alizarin Yellow and Azoviolet, were tested by noting the color in solutions with pH in the range 7-13. Azoviolet seemed to have the most distinctive color change in the desired range, $\mathrm{pH} 10$ to 12.5 (i.e., yellow at pH $\leq 11$ and purple at $\mathrm{pH} \geq 13$ )..

Using information provided by RBOF (Table I), we mixed a simulated waste and a waste adjustment solution containing the buffer. The original proposal was to add the anion regeneration solution (caustic) and cation regeneration solution (acid) to the waste adjustment solution.

Table I

\begin{tabular}{|c|c|c|c|c|c|c|c|c|c|}
\hline \multicolumn{2}{|l|}{ Recipe as given } & & \multicolumn{2}{|l|}{ Scaled Recipe } & & & & \multirow[t]{2}{*}{ moles } & \multirow{2}{*}{$\begin{array}{l}\text { moles } \\
\text { lliter }\end{array}$} \\
\hline & & & scale factor & $1 E+05$ & & & & & \\
\hline \multicolumn{10}{|l|}{ Anion Solution } \\
\hline 3066 & LH2O & & 0.03066 & LH2O & & 30.66 & $\mathrm{~mL} \mathrm{H2O}$ & & \\
\hline 273 & \multicolumn{2}{|c|}{$\mathrm{L} 50 \% \mathrm{NaOH}$} & 0.00273 & \multicolumn{2}{|c|}{ L50\% NaOH } & 2.73 & $\begin{array}{l}\mathrm{mL} 50 \% \\
\mathrm{~N}=\mathrm{OH}\end{array}$ & 0.05 & 1.58 \\
\hline \multicolumn{10}{|l|}{$\begin{array}{l}\text { Cation } \\
\text { Solution }\end{array}$} \\
\hline 4087 & LH2O & & 0.04087 & LH2O & & 40.87 & $\mathrm{mLH2O}$ & & \\
\hline 409 & \multicolumn{2}{|c|}{ L50\% HNO3 } & 0.00409 & \multicolumn{2}{|c|}{ L50\% HNO3 } & 4.09 & $\begin{array}{l}\mathrm{mL} 50 \% \\
\mathrm{HNO}\end{array}$ & 0.04 & 0.91 \\
\hline Final soln. & & & & & & & $\mathrm{OH}=$ & 0.01 & 0.15 \\
\hline Rinse Water & & & & & & & & $\mathrm{POH}=$ & 0.82 \\
\hline Acid & & & & & & & & $\mathrm{pH}=$ & 13.1 \\
\hline 1362 & $\mathrm{LH} 2 \mathrm{O}$ & & 0.01362 & $\mathrm{LH} 2 \mathrm{O}$ & & 13.62 & $\mathrm{mLH2O}$ & & \\
\hline \multicolumn{10}{|l|}{ Base } \\
\hline 1048 & $\mathrm{LH} 2 \mathrm{O}$ & & 0.01048 & LH2O & & 10.48 & $\mathrm{~mL} \mathrm{H} 2 \mathrm{O}$ & & \\
\hline Final soln. & & & & & & & & $\mathrm{pH}=$ & 13.0 \\
\hline Total water & 9563 & $\begin{array}{l}\text { Liler } \\
\mathbf{s}\end{array}$ & & 0.096 & Liters & 95.63 & $\mathrm{~mL}$ & & \\
\hline Total volume & 10245 & $\begin{array}{l}\text { Liter } \\
\text { s }\end{array}$ & & 0.102 & Liters & 102.45 & $\mathrm{~mL}$ & & \\
\hline \multicolumn{10}{|c|}{ Waste Adjustment } \\
\hline 1892 & LHEO & & 0.01892 & LH2O & & 18.92 & $m L H_{2 O}$ & & \\
\hline \multicolumn{10}{|l|}{$\mathrm{Nat} \mathrm{COO}_{3}$} \\
\hline 445 & $\mathrm{~kg}$ & & 0.00445 & $\mathrm{~kg}$ & & 4.45 & 9 & & \\
\hline \multicolumn{10}{|l|}{$\mathrm{Na2} \mathrm{CO} 3$} \\
\hline 563.2 & $\mathrm{~kg}$ & & 0.005632 & $\mathrm{~kg}$ & & 5.632 & $g$ & & \\
\hline \multicolumn{10}{|l|}{$\mathrm{NaNO}_{2}$} \\
\hline 719.6 & $\mathrm{~kg}$ & & 0.007196 & $\mathrm{~kg}$ & & 7.196 & 9 & & \\
\hline
\end{tabular}

However the amount of salts required for the waste adjustment solution proved to be insoluble.

We then proposed adjusting the $\mathrm{pH}$ of the solution with $\mathrm{CO}_{2}$ gas, via the reaction

$$
\mathrm{OH}^{-}+\mathrm{CO}_{2} \rightarrow \mathrm{HCO}_{3}^{-}
$$


The apparam for bubbling $\mathrm{CO}_{2}$ through the solution is shown in Fig. 1. Dry ice (solid $\mathrm{CO}_{2}$ ) was placed in a stainless steel tube then could be capped on both ends. The dry ice was allowed to sublime at room temperanure, providing a flow of $\mathrm{CO}_{2}$ gas. This $\mathrm{CO}_{2}$ gas exaped through a side arm fitted with Tygon tubing and bubbled through the solution. The rate of gas evolution was not measured, but it appeared vigarous and was sufficient to lower the $\mathrm{pH}$ of our initial pH 12.5 solution to $\mathrm{pH} 10$ within a few minutes. If the $\mathrm{CO}_{2}$ flow were allowed to continue, it is possible to over-neutralize to a pH of 8-9, the $\mathrm{pH}$ of a $\mathrm{HCO}_{2}^{-}$solution. In actual plant operation it may be preferable to use CO2 from a gas cylinder rather than subliming dry ice.

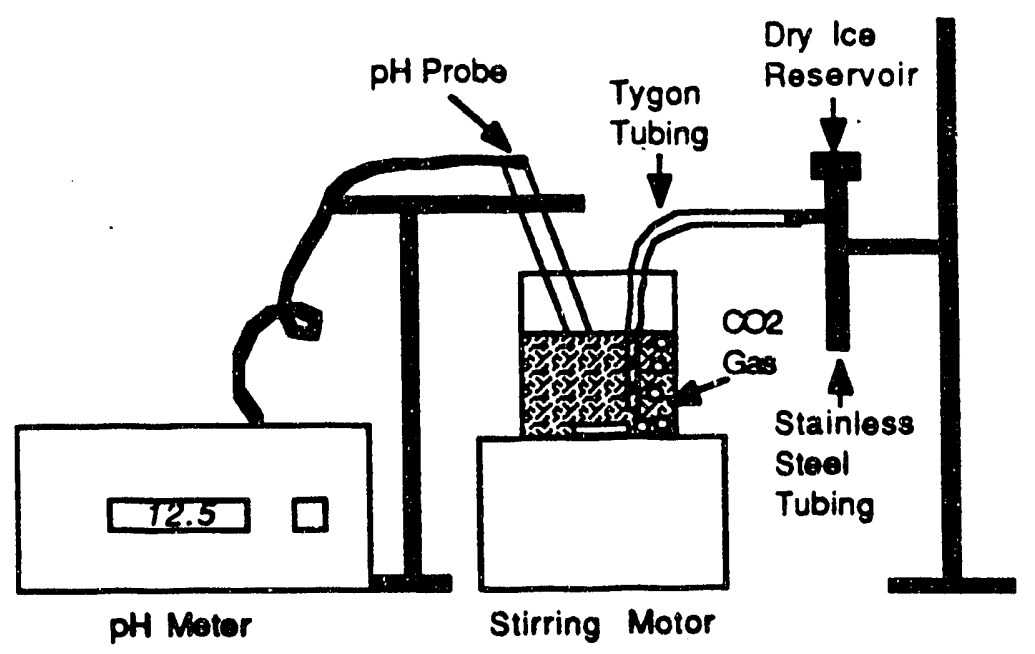

Fig. 1.

The solution was allowed to sit in an open beaker. The pH appeared to drop by $0.2 \mathrm{pH}$ units over 48 hours. It is not known if this change is outside expected experimental error.

1 Personal communicarion, S. W. Stump, 244-2H.

2 "Limitations on Waste Tank Contents," DPSTS-241-5.01; "Limitations on Waste Tank Contents During Sludge Processing and Storage," DPSTS-241-5.03.

3 Young, J. E. "Treatment of "MAGNUSPRAY 205" Hazardous Waste," SRL-ADS-91-0622.

4 Baumann, E. W. "Colorimetric Determination of High pH with Azoviolet Indicator," WSRC-TR-90-12.

5 Baumann, E. W. and Buchanan, B. R. "Colorimetric pH Determination with Compurer Modeling," Applied Spectroscopy, 45, 1991, 632.

6 For instance HACH model DR/3000 spectrophotometer.

7 Hyder, M. L.; Perties, W. C.; Trompson, M. C.; Bumey, G. A.; Russell, E. R.; Holcomb, H. P.; and Landon, L. F.; "Processing of Irradicted, Enriched Uranium Fuels at the Savannah River Plant," DP-1500, p 7.25. 

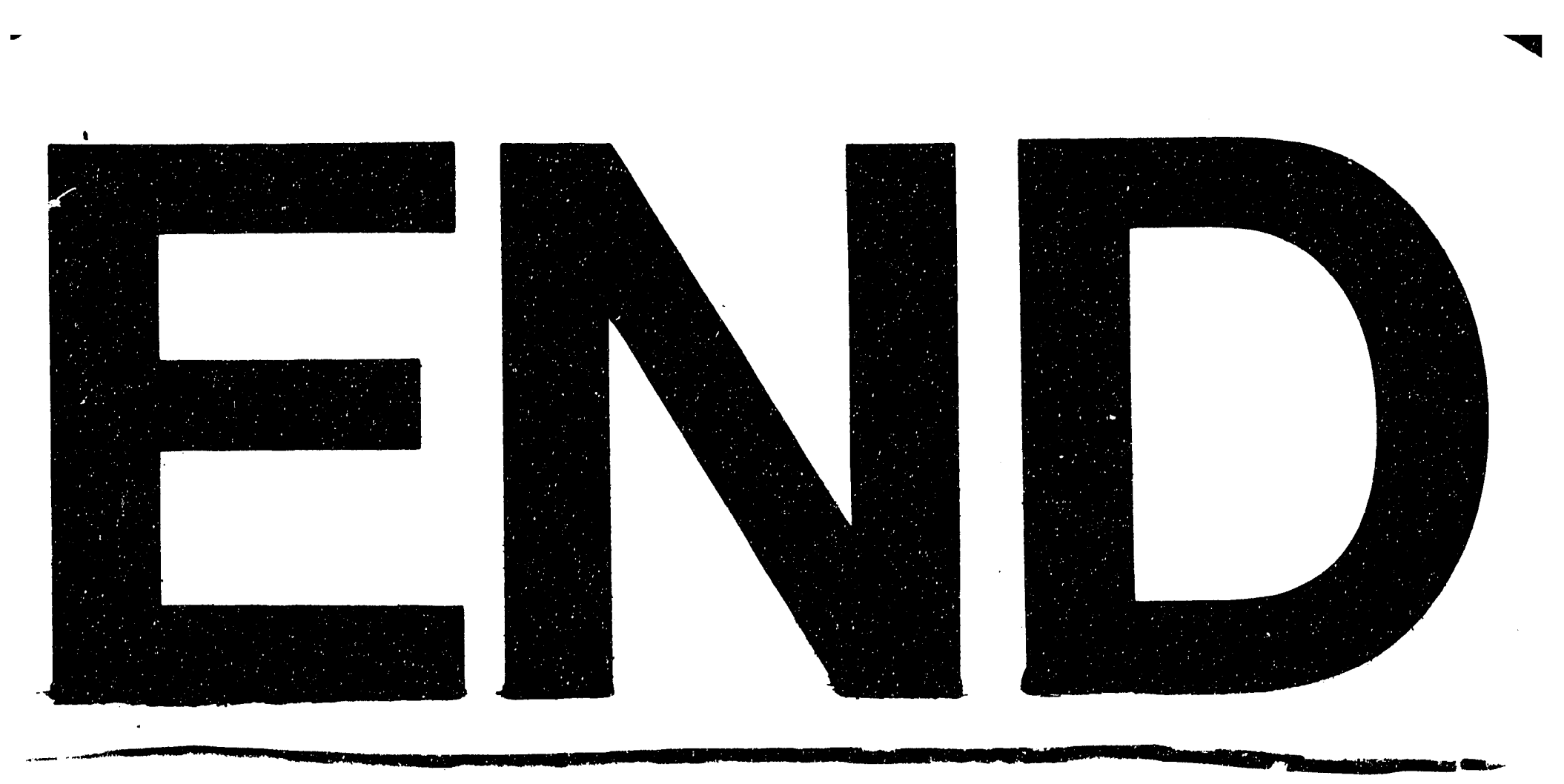

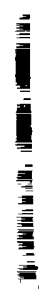
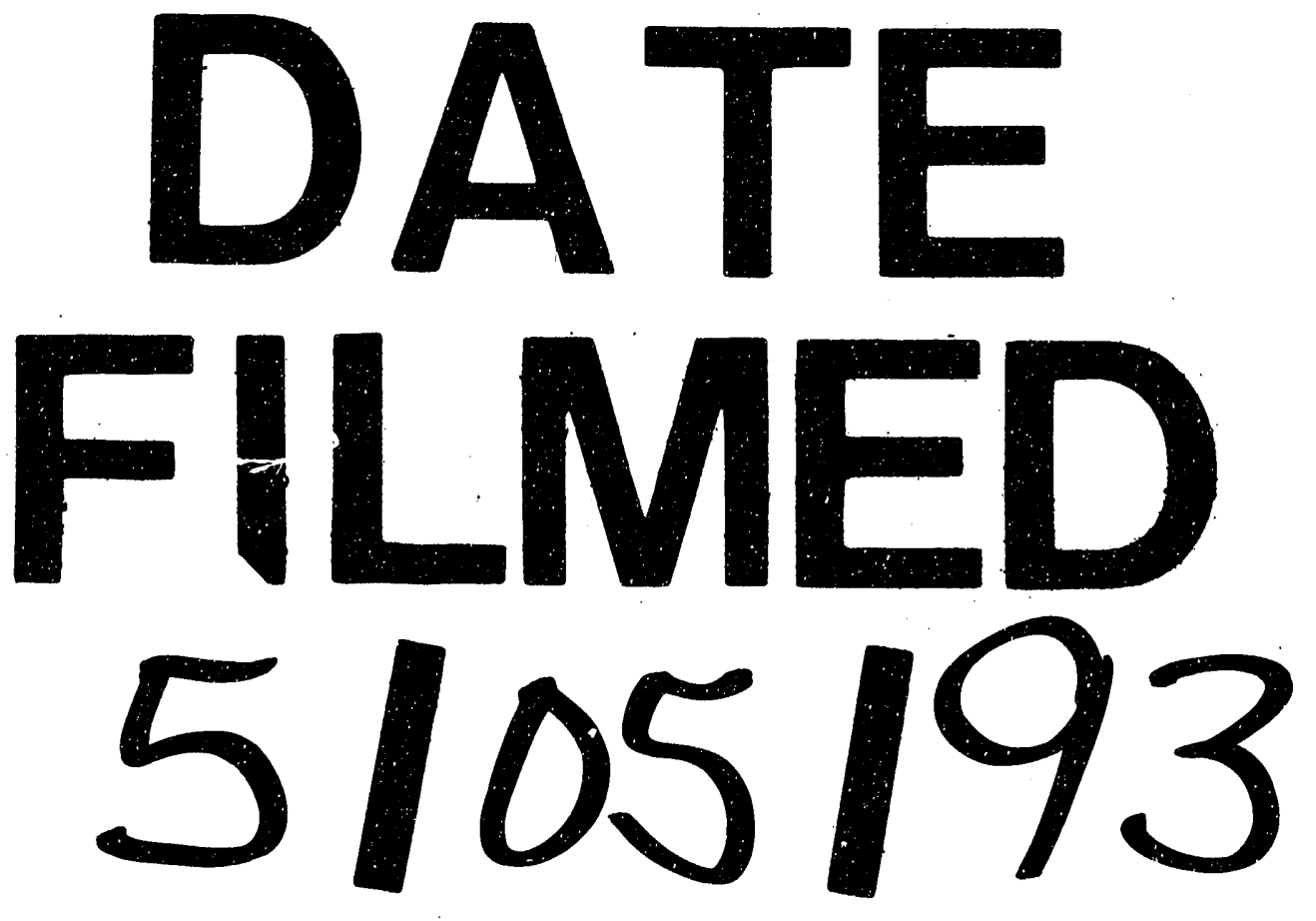
1 